\title{
Rastros da Shoah na recente literatura brasileira
}

\section{The traces of Shoah in the recent Brazilian literature}

\author{
Marcelo Ferraz de Paula* \\ Universidade Federal de Goiás \\ marcelo2867@gmail.com
}

RESUMO: O artigo discute a presença da Shoah em obras recentes da literatura brasileira, buscando compreender aspectos formais e éticos relacionados à investida artística neste tema. O diálogo teórico-crítico principal é com o ensaio "Literatura da Shoah no Brasil”, de Márcio Seligmann-Silva (2007), e as reflexões são realizadas com base no exame de $O$ que os cegos estão sonhando?, de Noemi Jaffe, K. Relato de uma busca, de Bernardo Kucinski, e O irmão alemão, de Chico Buarque.

PALAVRAS-CHAVE: Shoah. Testemunho. Chico Buarque. Noemi Jaffe. Bernardo Kucinski.

ABSTRACT: This paper discusses the presence of Shoah in recent works of Brazilian literature, seeking to understand formal and ethical aspects connected to the artistic approach of this theme. The main theoretical-critical dialogue is with the article "Literatura da Shoah no Brasil", by Márcio Seligmann-Silva (2007), and the reflections are based on the examination of $O$ que os cegos estão sonhando?, by Noemi Jaffe, K. Relato de uma busca, by Bernardo Kucinski, and $O$ irmão alemão, by Chico Buarque.

KEYWORDS: Shoah. Testimony. Chico Buarque. Noemi Jaffe. Bernardo Kucinski.

\section{Considerações iniciais}

No artigo "Literatura da Shoah no Brasil", publicado pela primeira vez em 2007, Márcio Seligmann-Silva faz um pertinente balanço da presença da Shoah nas letras brasileiras. O estudo retoma as contribuições do trabalho pioneiro de Regina Igel (1997) sobre a temática no Brasil, atualizando o seu panorama e comentando algumas obras de destaque. Em seu exame, o crítico é incisivo ao avaliar o impacto diminuto da catástrofe na literatura do nosso país:

A presença da Shoah na Literatura brasileira é, devemos deixar claro logo de saída, extremamente marginal. Apesar da participação

\footnotetext{
*Professor adjunto do Departamento de Estudos Literários da Universidade Federal de Goiás (UFG).
} 
brasileira nas frentes de batalha da Segunda Guerra Mundial contra as forças nazistas, não se pode perceber na cultura deste país a presença forte deste fato. Mesmo hoje em dia, no início do século 21, com a importância atribuída pelos estudos culturais ao estudo dos relatos de sobreviventes e de minorias perseguidas, este panorama não mudou, ao menos com relação à Shoah. Os sobreviventes que por uma série de motivos variados acabaram aportando no Brasil, não encontraram aí um público acolhedor aos seus testemunhos. E, da mesma forma, o escritor brasileiro que eventualmente se voltou para este tema, tampouco respondeu a uma questão cultural vista como importante. (SELIGMANN-SILVA, 2007, s/p)

Presença escassa, mas longe de ser desprezível, conforme o autor busca demonstrar ao longo de sua reflexão. Para isso diferencia os testemunhos primários - escritos diretamente pelos sobreviventes - dos testemunhos secundários produzidos principalmente por familiares de imigrantes comprometidos com a reconstituição das memórias do horror nazista. Nos variados níveis de afastamento (espacial, temporal e afetivo) do evento retratado e nos múltiplos graus de estetização do relato, Seligmann-Silva reconhece nesta produção uma espécie de "resumo concentrado" da literatura da Shoah escrita mundo afora, na medida em que o tratamento do tema no Brasil incorpora os principais impasses, aporias e estratégias de representação presentes nos testemunhos canônicos. Em detrimento da aparente "falta de diálogo desta produção com o veio da literatura nacional tradicionalmente mais valorizado" (SELIGMANN-SILVA, 2007, s/p), o autor ressalta a importância do tema e a qualidade de seu tratamento como marcas indeléveis da abordagem de memorialistas e escritores como Nichthauer, Moacyr Scliar, Samuel Rawet e Roney Cytrynowicz.

Sem a pretensão de atualizar quantitativamente os estudos de Seligmann-Silva e Regina Igel - isto é, de inventariar exaustivamente obras que vieram à tona após a publicação de seus trabalhos -, formulamos neste artigo a hipótese de que ocorreu uma mudança importante na abordagem literária da Shoah em obras brasileiras publicadas ao longo da segunda década do século XXI. Neste período as pesquisas sobre o testemunho, que tiveram um salto significativo no início dos anos 2000, consolidaram-se de vez no Brasil, como pode ser comprovado pela quantidade e diversidade de simpósios, dossiês, traduções, coletâneas e projetos de pesquisa dedicados ao tema ao longo dos últimos anos. Este avanço no campo de estudos acompanhou e impulsionou, sem dúvida, um interesse cultural mais amplo pelas 
questões ligadas à memória e à identidade e tem nas investigações sobre a construção das memórias da Shoah uma de suas vertentes incontornáveis.

Num sentido mais amplo, igualmente podemos apontar eventos que, neste intervalo temporal, contribuíram para um interesse revigorado nas questões éticas, humanitárias, filosóficas e jurídicas acionadas no Brasil pela escrita testemunhal. A duras custas tivemos no país uma Comissão da Verdade que, ainda que de forma retardatária e limitada quando comparada aos vizinhos do cone sul, trouxe alguma esperança de esclarecimento e responsabilização dos crimes cometidos nos porões da ditadura militar (1964-1985) e consequentemente animou o debate público sobre essa triste página de nossa história.

Em outro extremo, acompanhamos a ascensão de movimentos autoritários com forte matiz revisionista e negacionista, que se tornaram uma voz política estridente, influente e agressiva nos últimos anos. Como forma de denunciar, compreender e resistir a esses ideais regressivos, com forte enraizamento na sociedade brasileira, a literatura também intensificou a recorrência de temas ligados à opressão e aos traumas históricos, buscando deles extrair um sentido que ajudasse a compreender as ameaças do presente. Como emblema do mal absoluto, a Shoah passa a ser evocada tanto como exemplo maior de um passado que não pode ser esquecido, como também é mobilizada como exemplo eloquente dos riscos que o ódio, a definição de um inimigo a ser extirpado, a busca do embate e da polarização e a redução obtusa da política à moral trazem para a vida pública. Como contraponto ao avanço da extrema-direita em diversos lugares do mundo, a memória da Shoah voltou a inspirar obras artísticas fundamentais da contemporaneidade, na mesma medida em que o tema voltou a "estar na moda", sendo amplamente evocado em filmes, bestsellers, seriados de tevê e atrações turísticas. Produtos culturais que operam na zona tênue entre a urgente atualização dessa memória em tempos cinzentos e sua banalização como objeto de consumo.

Assim como Seligmann-Silva, levaremos em conta neste estudo apenas obras narrativas, deixando de fora de nosso horizonte analítico, por exemplo, o repertório poético, onde o tema também comparece com algum destaque, como na visceral "Balada dos mortos dos campos de concentração", de Vinícius de Moraes, ou no minimalista e doloroso "lua à vista", de Paulo Leminski. É, contudo, nas formas narrativas que encontramos maior variação de abordagens e procedimentos relacionados à representação da Shoah. Em livros recentes, essa abordagem ora se 
aproxima do romance histórico, como em A segunda pátria (2015), de Miguel Sanches Neto, ou O cisne e o aviador (2014), de Heliete Vaitsman, ora revisita a identidade judaica a partir de um ângulo mais intimista, como em O Diário da Queda (2011), de Michel Laub, ou nos contos breves e introspectivos de Cíntia Moscovich.

$O$ interesse em esquadrinhar essa produção mais recente comparece também no artigo "Uma história concisa do Holocausto na literatura brasileira", de Berta Waldman (2019). A autora se apoia no já mencionado livro de Regina Igel (Imigrantes e judeus/escritores brasileiros) acrescentando outros nomes das novas gerações ao seu panorama e colocando em evidência alguns problemas metodológicos para o estabelecimento de uma historiografia da Shoah (ou Holocausto, como prefere a autora) na literatura brasileira. Entretanto, acaba não entrando em sua reflexão as obras que selecionamos como corpus para essa discussão: $O$ que os cegos estão sonhando?, de Noemi Jaffe, K. Relato de uma busca, de Bernardo Kucinski, e O irmão alemão, de Chico Buarque.

Num sentido contrário à conclusão de Seligmann-Silva - que observou nas obras por ele analisadas uma relevância cultural e qualidade artística alta, mas pouco vínculo com as linhas literárias mais prestigiadas da literatura brasileira - vemos nestes romances mais recentes um diálogo intenso com formas de narrar consagradas na literatura contemporânea. Assim, as obras que leremos não causam no leitor a impressão de se direcionarem prioritariamente a um nicho específico de leitores judeus ou de apresentarem estratégias narrativas estranhas às linhas mais debatidas da produção atual. Ao contrário, incorporam elementos amplamente identificados e estudados como característicos dessa produção, como o hibridismo de gêneros, a autoficção, o multiperspectivismo e o embaralhamento deliberado entre $o$ "real" e o ficcional.

Como não restringimos este estudo a obras que tenham a Shoah como tema central de seu enredo, evitamos caracterizar esses livros como "literatura da Shoah". Todavia, acreditamos que nos textos analisados há muito mais do que referências dispersas aos campos de concentração e extermínio nazista; tal presença cumpre uma função narrativa que vai além da alusão pontual e assume um papel decisivo nessas obras, ainda que nos livros de Kucinski e Buarque não seja a Shoah o foco central e exclusivo das histórias narradas. 


\section{0 que os cegos estão sonhando?}

O que os cegos estão sonhando? é um livro bastante peculiar, publicado por Noemi Jaffe em 2012 e constituído de três narrativas justapostas. A primeira é o Diário de Lili Jaffe (1944-1945). Lili é mãe de Noemi, sobrevivente do campo de Auschwitz. Escreveu o diário na Suécia, meses após a libertação dos campos, mantendo, entretanto, uma escrita que recupera e presentifica em sua narrativa os terríveis dias de aprisionamento.

O segundo texto ocupa mais da metade do livro, possui o mesmo título da obra e abarca as reflexões da escritora Noemi Jaffe sobre sua experiência como filha de sobrevivente. Essa parte se notabiliza pelo hibridismo e a fragmentação, numa mescla de escrita ensaística, narrativa memorialística e lirismo. Alternam-se fragmentariamente, entre os seus curtos capítulos, quatro núcleos: 1) a história da mãe e da família após a libertação e de sua vinda para o Brasil, portanto depois dos eventos narrados no diário; 2) o relato pungente do modo como a memória traumática é herdada pelo núcleo familiar íntimo e os desafios éticos e subjetivos de convertê-la em literatura; 3) uma tentativa de interpretação crítico-afetiva do diário materno, com um diálogo constante com outras obras testemunhais e com estudos teóricos sobre o testemunho; e 4) o relato de uma visita ao memorial de Auschwitz, em 2009, junto com a mãe e com sua filha, e o impacto dessa visita. A terceira parte, mais breve, ressalta a terceira geração de mulheres da família, sendo escrita justamente pelo outro elo dessa viagem ao memorial: a filha de Noemi e também escritora Leda Cartum.

A pergunta que dá título ao livro é recuperada de uma fala da mãe, marcando o seu português de estrangeira, cuja dureza inusitada da sintaxe manifesta uma carga poética vista pela filha como síntese de seu mundo pessoal:

Um dia, ao telefone, ela, que gosta de ficar imaginando situações, perguntou à filha: "Filha, o que os cegos estão sonhando?". [...]. Então a filha entendeu e se lembrou que a mãe confunde os usos do presente simples e do presente contínuo. "O que os cegos estão sonhando", na verdade, é "Com que os cegos sonham?". Mas, de uma forma inesperada e subitamente bela, aquela frase, em sua suspensão do tempo, em seu deslocamento gramatical e semântico e em seu significado autônomo, como que independente de qualquer lógica narrativa, sintetiza exatamente o estar-no-mundo da mãe. (JAFFE, 2013, p. 183) 
Ao congregar as narrativas dessas três mulheres, tocadas de diferentes maneiras pela memória traumática da Shoah, o livro entrelaça também diferentes formas de lidar com a escrita testemunhal: o testemunho primário versus o secundário, a escrita mais referencial/documental versus o trabalho estético depurado, a necessidade de fidelidade estrita aos fatos versus a urgência da mediação ficcional como caminho para representar o inverossímil brutal da Shoah. A respeito disso, já pudemos afirmar que:

Para enfrentar esses dilemas - e a autora faz questão de enfatizar que "tudo diante da guerra, e, mais ainda, dessa guerra, é motivo de dilema" (Jaffe, 2012, p. 137) - Noemi Jaffe se coloca como autora, narradora, intérprete e personagem de sua própria experiência como filha de sobrevivente. [...] A abundância de tons e semitons parece indicar tanto a dificuldade de lidar com uma matéria esquiva, que não pode ser satisfatoriamente examinada a partir de uma estilização uniforme, como também revela o caráter indizível da experiência com a qual se debate. Às vezes, num mesmo capítulo, a filha vai da interpretação amorosa do diário da mãe a uma reflexão histórica de amplo alcance. De um capítulo para outro, passamos de uma narrativa que imagina ficticiamente o futuro das pessoas que a mãe conheceu nos campos para um inventário poético de objetos exibidos no memorial de Auschwitz. Nesse mosaico vertiginoso, com suas fissuras e enlaces, funda-se uma imagem altamente original do horror dos campos, sem concessões aos obstáculos de verbalização que o tema provoca. (PAULA, 2018, p. 290)

As tensões entre essas diferentes perspectivas se evidenciam de modo mais consciente no relato da filha, no qual a razão de escrever o livro e os limites de sua estetização geram um questionamento metalinguístico:

[...] a mãe, por ter vivido tão maciçamente algo que é inapelavelmente real, não suporta as intervenções súbitas do inesperado em seu cotidiano tão bem armado, e as rechaça como ficção. E a filha, por ter tido uma mãe que viveu esta verdade, por não tê-la vivido, por só conhecer os fatos parcialmente [...] precisa ficcionalizar quase tudo o que vive e acaba rechaçando os limites do real como impertinências opressivas. (JAFFE, 2012, p. 205-206)

A mãe quer muito ver o livro pronto [...]. Sua impressão deve ser a de que a filha está contando sua história de forma mais bem escrita, mais arranjada do que ela pode fazer. Como explicar a mãe que não é isso que ela está fazendo? Qual será a reação da mãe, quando ela vir que este livro é um apanhado de retalhos, de divagações, de memórias soltas, de tentativas rasgadas de interpretações misturadas e lembranças coladas? (JAFFE, 2012, p. 208) 
No diário da mãe é bastante nítido o trabalho de expurgação pessoal por meio da palavra, próprio de muitos sobreviventes. Não se observa maiores pretensões literárias: sua escrita busca reconstituir factualmente a experiência dos Lager numa cadeia cronológica, fixando na narrativa as violências sofridas, as estratégias de sobrevivência e os anseios de reconstrução de uma nova vida. Seligmann-Silva afirma que neste tipo de narrativa predomina o registro "representacionista", abundante principalmente no imediato pós-guerra, quando a instrumentalização da escrita dos sobreviventes visava contribuir com o esclarecimento dos fatos ocorridos, tanto numa perspectiva jurídica quanto histórica (SELIGMANN-SILVA, 2007, s/p), além de atender a uma necessidade pessoal de expressão e ordenação catártica das lembranças.

Por sua vez, as reflexões de Noemi Jaffe acionam um vasto conjunto de referências, tanto afetivas quanto intelectuais, abordando as dificuldades de lidar com o silêncio da mãe, as memórias lacunares e os muitos desencontros entre as duas, atravessados sempre pelo trauma de Auschwitz. O diário materno é, assim, a caixa preta de uma experiência devastadora que a mãe optou por tentar esquecer posteriormente, falando pouco com as filhas sobre sua vida no campo. Por outro lado, ele é igualmente uma metonímia do impacto do trauma silenciado, seja na vida familiar seja no debate público contemporâneo:

Faltam, no máximo, vinte anos para que os sobreviventes desapareçam, morram. Quando isso acontecer, outra etapa desta história vai começar e é preciso preparar-se para ela. O que serão os campos de concentração daqui a cinquenta anos? Um nome? A história deverá preparar-se para isso? A palavra Auschwitz será como a palavra Troia, a palavra Peloponeso, a palavra Manchúria? (JAFFE, 2012, p. 186, grifos da autora)

Na escrita de Noemi Jaffe o tratamento literário é evidente, embora sempre atento ao risco da estetização do drama familiar que a autora enfrenta imprimindo uma exigente ética de escrita. O breve texto de Leda Cartum, por sua vez, traz uma forte nota poética à terceira parte do livro, assumindo uma posição ainda mais afastada em relação ao testemunho primário da avó-sobrevivente, mas ciente também de seu impacto na história íntima da família, a qual, por sua vez, o livro demonstra estar intimamente conectada à história do judaísmo no Brasil.

Na perspectiva da filha de sobrevivente, a memória do horror é colocada nos termos de um trauma herdado, cujo impacto se evidencia tanto nas cicatrizes físicas 
e psicológicas da mãe quanto no sentimento de culpa da filha, pois "Ser filho de sobrevivente contém, em algum lugar remoto e inóspito da memória, a tentação de ter estado no lugar do sobrevivente [...] deixa nos filhos uma pequena culpa, uma pequena falta" (JAFFE, 2012 p. 115). Ao mesmo tempo, o impasse da filha é a versão extrema de uma responsabilidade cultural, social e política mais ampla, que diz respeito, como indica a passagem acima citada, ao risco de esquecimento, tornado mais dramático com a morte dos últimos sobreviventes e evidenciando o papel primordial da testemunha solidária, aquela que não vai embora diante da narrativa insuportável do outro e que pela transmissão a preserva da morte simbólica (GAGNEBIN, 2009, p. 57).

Por suposto, essa escuta não envolve nenhum heroísmo e é assumida a partir de uma autocrítica bastante rigorosa. Afinal, o risco do esquecimento convive ordinariamente com o risco da banalização da memória, do excesso de uma engessada memória monumental e cívica. Assim, o livro também traz o dilema sobre a necessidade de mais uma obra sobre o holocausto:

Alguns dizem que já não faz mais nenhum sentido escrever algo sobre o nazismo. Tudo, supostamente, já foi escrito, falado, filmado, fotografado, explorado até o limite. [...] É possível que o holocausto tenha se esgotado e cansado enquanto fonte de aprendizado. Mas isso, supostamente, em seu sentido coletivo. Como experiência individual, não existe tal coisa como cansaço do que foi vivido. (JAFFE, 2012, p. 184)

Se podemos mesmo pensar a "literatura da Shoah" no Brasil como uma síntese das diversas vertentes consagradas da abordagem da catástrofe, $O$ que os cegos estão sonhando? é, por si só, um mosaico condensado dos diversos modos de lidar, ética e textualmente, com as memórias do massacre. A obra conjuga formas e perspectivas que se complementam e se tensionam, em busca da expressão parcial de algo que sabidamente escapa à representação.

\section{K. Relato de uma busca}

Avançando para outra obra representativa da presença da Shoah na recente produção literária brasileira, abordamos o célebre romance $K$. Relato de uma busca, de Bernardo Kucinski. A obra vem sendo amplamente reconhecida como uma das 
mais impactantes e complexas representações da violência engendrada pela ditadura militar brasileira e destaca, em primeiro plano, o drama dos familiares de desaparecidos políticos em sua busca pelo corpo de entes queridos assassinados pelo regime. $K$. tornou-se um livro central no debate sobre o testemunho no Brasil, merecendo, de modo crescente nos últimos anos, uma vasta fortuna crítica. A nota explicativa que abre o livro - "Caro Leitor: Tudo neste livro é invenção, mas quase tudo aconteceu." (KUCINSKI, 2014, p. 8)" - assinala, como ponto de partida, essa zona sensível entre o relato testemunhal e a criação ficcional. A história aborda o desaparecimento de Ana Rosa Kucinski (irmã do autor, nunca nomeada ao longo do livro) e de seu marido, ambos militantes da Aliança Libertadora Nacional. O protagonista é o pai de Ana Rosa, nomeado kafkianamente como K. Inicialmente o pai busca pistas sobre o paradeiro da filha, mas, paulatinamente, conforme toma ciência dos atos brutais da repressão política, reconhece o seu aprisionamento, tortura e morte, passando a procurar informações sobre o paradeiro de seu corpo. Debilitado física e emocionalmente, o personagem é enredado pelo aparato da burocracia estatal, já armada para ocultar os crimes cometidos pelo regime e desqualificar a dor de suas vítimas.

Em primeiro plano temos, portanto, a procura atormentada de um pai pela filha no contexto da ditadura miliar brasileira, mas este foco não obstrui a relevância da Shoah na construção da trama. Na obra, K. é um emigrante polonês que participou da resistência à invasão nazista em um partido sionista de esquerda. Posteriormente, com o início da guerra, fugiu de seu país natal em direção ao Brasil. Ele consegue escapar do nazismo, não sem deixar pelo caminho várias pessoas queridas que acabaram levadas para os campos de extermínio:

K. tinha trinta anos quando foi arrastado pelas ruas de Wloclawek, acusado de subversão pela polícia polaca. Por isso emigrou às pressas, deixando mulher e filho, que só se juntariam a ele no Brasil um ano depois. Sua irmã, Guita, cinco anos mais velha, não tivera a mesma sorte. Morreu de frio na prisão. (KUCINSKI, 2014, p. 37)

Ao fixar-se no Brasil, ele passa a se dedicar à preservação do iídiche, traduzindo e escrevendo na língua mais afetada pelo projeto de extermínio nazista e que quase foi extinta durante a guerra. Obcecado por este trabalho, que de certa maneira visava reconstituir uma identidade perdida, K. mostra-se indiferente ao 
cenário de repressão política no país que o acolheu, não percebendo a militância de sua filha, os riscos que corria e, por fim, seu trágico desfecho. Somente várias semanas após o desaparecimento é que ele inicia a sua busca, já aturdido pelo sentimento de culpa que é habilmente construído através do discurso indireto livre, abundante ao longo da narrativa:

E como não perceber o tumulto dos novos tempos, ele, escolado em política? Quem sabe teria sido diferente se, em vez dos amigos escritores do iídiche, essa língua morta que só poucos velhos ainda falam, prestasse mais atenção ao que acontecia no país naquele momento? Quem sabe? Que importa o iídiche? Nada. Uma línguacadáver, isso sim que eles pranteavam naquelas reuniões semanais, em vez de cuidar dos vivos (KUCINSKI, 2014, p. 13-14)

O pai também "sentia a perda prematura da filha como uma punição, por seu coração estar sempre na literatura, nos amigos escritores" (KUCINSKI, 2014, p. 172). Mas não é apenas no âmbito do trauma pessoal de K. e da culpa que carrega que a Shoah comparece no romance. São diversas as comparações entre a situação da ditadura militar e a catástrofe dos judeus na Europa sob jugo nazista, conforme os exemplos abaixo:

As fotografias do álbum dos indigentes e desconhecidos o deprimiram. Nem na época da guerra na Polônia deparara com rostos tão maltratados e olhos tão arregalados de pavor. (KUCINSKI, 2014, p. 19)

Até os nazistas que reduziam suas vítimas a cinzas registravam os mortos [...] Eram execuções em massa, não era um sumidouro de pessoas. (KUCINSKI, 2014, p. 23)

Sente que sua filha foi tragada por um sistema impenetrável, diferente de tudo que ele havia conhecido, mesmo na Polônia. (KUCINSKI, 2014, p. 35)

Como se pode observar, as comparações carregam algo de controverso ${ }^{1}$, mas têm o intuito claro de ressaltar a violência da ditadura brasileira, bem como a crueldade

\footnotetext{
${ }^{1}$ Em Os visitantes (2016), Kucinski narra, também no limiar entre ficção e testemunho, a repercussão de K. Relato de uma busca. Já no primeiro capítulo do livro, o autor-personagem é confrontado por uma "velha com um número no braço", sobrevivente de Auschwitz, que lhe recrimina: "o senhor escreveu que os alemães registravam todas as pessoas que matavam, mas isso não é verdade!". Um dos argumentos que ele utiliza para se justificar, e que não é aceito pela senhora, é justamente o de que "ignorei um detalhe do holocausto para ressaltar a crueldade dos desaparecimentos no Brasil" (KUCINSKI, 2016, p. 12-13).
} 
por trás do desaparecimento dos corpos e a eficácia do sistema de desinformação forjado pelo regime para encobertar seus crimes. Uma tarefa política assumida pela obra de Kucinski é a de denunciar o esquecimento e a impunidade em relação à ditadura, denunciando abertamente o que ele considera um "mal de Alzheimer nacional" (KUCINSKI, 2014, p. 12). Nesse sentido, a evocação da memória da Shoah introduz na narrativa um contraponto importante, pois a catástrofe não apenas figura como evento-limite, de proporções drásticas, como sua memória segue bastante viva em projeções midiáticas e acadêmicas como emblema do mal extremo. A mazela da Shoah é conhecida e conta habitualmente com a disposição e sensibilidade de escuta de muito leitores, diferentemente do silêncio conivente que se estabeleceu sobre a ditadura. Assim, as comparações entre os dois eventos se sabem polêmicas, ou mesmo chocantes, e visam justamente abalar a sensação difusa de que tivemos uma ditadura amena, ou uma "ditabranda" como certa vez afirmou um jornal de grande circulação no país.

Ao comentar a dimensão delicada e polêmica da comparação entre catástrofes, Jeanne Marie Gagnebin assevera que tal procedimento deve levar em conta uma responsabilidade ética e um compromisso político com o presente:

o alvo das comparações não consiste em estabelecer vagas semelhanças, mas sim em mapear as diferenças e as especificidades. O método comparatista deve lutar, simultaneamente, contra a banalização - tudo é parecido com tudo - e, em particular, no estudo da Shoah e de outros genocídios, contra a tentação dos grandes sentimentos tão inefáveis quanto impotentes. (GAGNEBIN, 2000, p. 102-103)

Nesse sentido, tanto quanto a construção individual da memória a partir do testemunho, interessa o modo como essas memórias se situam em um contexto social e histórico de disputas e luta pela verdade no presente. O modo como a memória de uma catástrofe é evocada articula-se profundamente com o momento e as condições nas quais ela emerge. Kucinski explora o "excesso" de memória da Shoah como provocação ao esquecimento da sociedade brasileira em relação às mazelas da ditadura. As memórias (da Shoah e da ditadura) simultaneamente se contaminam com sua mácula e se energizam criticamente, de tal forma que o drama do pai privado do luto ecoa como símbolo de um país estagnado no recalque, pois "à impossibilidade 
do luto responde a impossibilidade do nascimento verdadeiro, pois somente o reconhecimento da morte permite a plenitude da vida" (GAGNEBIN, 2000, p. 110).

Numa das cenas mais comoventes do romance, K. pede ajuda a um rabino para velar a filha e incluir uma lápide alusiva à sua morte no cemitério judaico, mesmo sem a presença do corpo, argumentando que essa exceção já fora feita para as vítimas da Shoah cujos corpos foram incinerados. A estarrecedora resposta do líder religioso demonstra uma perpetuação da barbárie e da indiferença, mesmo entre aqueles que foram vítimas de uma violência análoga e, em tese, deveriam ser os mais compreensivos em relação ao horror do autoritarismo vigente no país ${ }^{2}$ :

O que você quer na verdade é um monumento em homenagem à sua filha, não é uma lápide, não é uma matzeivá; mas ela era terrorista, não era? E você quer que a nossa comunidade honre uma terrorista no campo sagrado, que seja posta em risco, por causa de uma terrorista? (KUCINSKI, 2014, p. 81)

Podemos concluir que em K. Relato de uma busca a Shoah comparece como a figuração de um horror que não pode ser esquecido, mas que não se esgota em si mesmo. Ao explorar a difusão do evento no imaginário social, o autor visa estabelecer contrapontos com a realidade brasileira, seja na culpa que K. carrega por imaginar ingenuamente que a mesma violência sofrida na Polônia não poderia lhe tocar no Brasil, seja por indicar a recorrência de métodos e formas de apagamento de rastros entre a Shoah e a ditadura brasileira. Assim, a comparação entre os eventos não visa, obviamente, colocar em discussão qual foi pior ou mais cruel, mas chamar atenção para a revolta necessária diante de ambos, já que estariam ligados historicamente:

Avrum o admoestara por comparar o que aconteceu com sua filha ao Holocausto. Nada se compara ao holocausto, disse; chegou a levantar, tão aborrecido ficou. O Holocausto é um e único, o mal absoluto. Com isso K. concordou, mas retrucou que para ele a tragédia da filha era a continuidade do Holocausto". (KUCINSKI, 2014, p. 79)

\section{Irmão Alemão}

\footnotetext{
2 Uma situação semelhante ocorre no capítulo que narra a omissão dos professores do Departamento de Química da USP, onde a filha era professora, ao votarem pela sua exoneração por abandono do cargo, mesmo cientes de que ela era uma desaparecida política. $O$ narrador ressalta a presença de professores judeus, exilados da guerra, no teatro perverso que fora aquela reunião departamental.
} 
Para finalizar este breve percurso, nos detemos no romance $O$ irmão alemão, de Chico Buarque, publicado em 2014. Ele também adota uma estratégia narrativa que deixa rarefeito o limiar entre ficção e realidade, constituindo, neste caso, um exemplo bastante emblemático de autoficção, conceito que aponta para a indeterminação performática entre os gêneros autobiográfico e romanesco, entre o material advindo da experiência empírica e a invenção artística (NORONHA, 2014). Tais elementos se evidenciam, sobretudo, na inclusão de documentos do arquivo familiar do autor, como textos alusivos à "veracidade" do narrado, e na semelhança entre nomes de personagens do romance e personalidades públicas, como o pai do protagonista, Sérgio Buarque de Hollander. ${ }^{3}$

Os episódios autobiográficos incorporados ao romance são facilmente reconhecidos por quem acompanha a vida pública de Chico Buarque, mas o autor faz questão de rasurá-los, de implodir seus limites, afastando de antemão qualquer expectativa de fidelidade irrestrita aos fatos. Cumpre salientar que na autoficção, de modo distinto da abordagem testemunhal tradicional, estas marcas do "real" não surgem necessariamente com a finalidade de enfatizar/atestar um compromisso ético diante dos eventos abordados, mas sim visando embaralhar o real e o imaginário, desestabilizando os dois domínios, buscando reconstruir na escrita uma outra vida possível e levando à máxima potência a ideia de que toda autobiografia é em última instância construção, é ficção.

No enredo do livro, o narrador-personagem Ciccio é um jovem de classe média urbana, filho de um importante intelectual, vivendo numa casa habitada por livros e segredos, em um Brasil em polvorosa com a ditadura militar assumindo seu momento de maior tirocínio, no início dos anos 1970. Ciccio é avesso ao conservadorismo do regime, mas alheio também a qualquer anseio de mobilização efetiva, demonstrando uma postura que oscila entre o pedantismo e a apatia: "os colegas me censuravam sobretudo o que lhes parecia um ar meio blasé, numa época de grande efervescência política” (BUARQUE, 2014, p. 47). Essa dubiedade, com algo de cinismo, se mostra, por exemplo, nos momentos em que critica o autoritarismo do governo, especialmente seu moralismo tacanho, mas logo em seguida se empolga com a expectativa de conquistar um cargo de professor graças ao afastamento de muitos profissionais perseguidos pelo regime.

\footnotetext{
${ }^{3}$ Neste caso o escritor joga com um pequeno erro de digitação em um documento para reconstruir a figura do historiador Sérgio Buarque de Hollanda, pai de Chico.
} 
Os conflitos familiares assumem papel central na obra: de um lado, a rivalidade com o "irmão brasileiro", com o qual disputa edipianamente a atenção do pai, os mimos da mãe e o interesse sexual das jovens mulheres que frequentam seus círculos de amizade; de outro lado, o "irmão alemão" do qual o narrador toma notícia casualmente, quando encontra uma carta em um dos livros do pai, mencionando um filho que ele havia deixado na Alemanha, nos anos 1930. Este irmão misterioso tornase uma espécie de projeção do narrador, que passa a idealizar seus gostos e atitudes, estabelecendo com sua imagem uma identificação narcísica. A ação narrativa se concentra na busca do protagonista por esse irmão misterioso, sobre o qual a família mantém silêncio absoluto.

A narrativa em primeira pessoa nos permite acompanhar a mente turbulenta de Ciccio. O relato dos eventos vividos pelo personagem se bifurca em conjecturas, devaneios, possibilidades, planos e fabulações. É difícil para o leitor separar as hipóteses plausíveis que ele formula ao longo do romance das obsessões, traumas e atos falhos que operam em sua procura. Essa conjugação vai deformando ironicamente a racionalidade esperada das narrativas investigativas tradicionais, situando a obra nas versões pós-modernas do romance policial falhado, cujas pistas não levam a uma resolução lógica do sentido buscado. As frases sinuosas e os parágrafos longos reforçam, no plano formal, essa sensação de desorientação da busca, cujos indícios se fundamentam mais nas obras literárias que ele lê e em projeções do seu inconsciente do que no jogo perspicaz de pistas, evidências e conclusões.

É por meio das divagações do narrador que a Shoah entrará na história, ocupando papel importante em sua estrutura. A certa altura da busca pelo irmão alemão, Ciccio encontra uma carta endereçada ao pai pedindo documentos que confirmassem a sua origem, para com isso atestar que Sérgio Ernst - o filho alemão que se encontrava àquela altura em um orfanato - não é judeu. Ciccio encontra também cartas do pai relatando a dificuldade de obter esses documentos comprobatórios no Brasil e sua preocupação com o destino do filho. A partir disso, Ciccio passa a imaginar um desfecho trágico para o irmão: ele teria sido assassinado nas câmaras de gás nazistas. Como ocorre ao longo do romance, a vaga conjectura transforma-se rapidamente numa certeza para ele. O impacto desse temor aparece em sonhos, carregados de sugestões: 
Recordo quantas vezes sonhei com ele, a cada sonho com uma cara diferente, caras que se transfiguravam no aquário dos sonhos (BUARQUE, 2014, p. 108)

[no sonho há] ratos que parecem pombos, de bebês, de fetos e de mães com seios murchos, mas necessito chegar de qualquer maneira lá no cume, que será um posto de salvamento ou um forno crematório. Cá estou, e a poça de sangue fresco no capacho é um bom auspício, sinal de que meu irmão judeu ainda vive, mesmo vazando sangue na escada rolante de cimento que leva a um aposento repleto de livros (BUARQUE, 2014, p. 141)

A passagem acima sintetiza, em registro expressionista, diversos níveis do romance: os conflitos familiares, a onipresença dos livros - tanto na construção do espaço da casa familiar como na ampla rede intertextual e metalinguística que o livro formula -, a busca frustrada, a violência autoritária que eclode em fantasmagorias íntimas.

Assim como em K. Relato de uma busca, a evocação da Shoah está articulada a uma crítica corrosiva da ditadura militar brasileira. A comparação entre o regime nazista e os expedientes da ditadura comparecem também no romance de Chico Buarque. Porém, enquanto no livro de Kucinski tais comparações são feitas através do discurso indireto livre e servem principalmente para destacar o horror do regime brasileiro, em O irmão alemão tal alusão surge na fala de personagens secundários e encontra o ceticismo de Ciccio, imerso em sua letargia política:

O Christian me adverte que boa parte dos garçons, porteiros e choferes de táxi da cidade são informantes da polícia, para quem o mero conhecimento da língua russa pode ser comprometedor. $\mathrm{E}$ quando em cochicho ele equipara nosso Estado policial ao da Alemanha nazista, penso que já exagera um pouco. (BUARQUE, 2014, p. 133)

O desdém do narrador pela afirmação do amigo reforça a sua postura ao longo do romance: postura de indiferença em relação à repressão a sua volta e de predisposição a fabular um mundo distante, afim dos grandes eventos históricos e das grandes narrativas literárias que formam o repertório paterno, ao qual o personagem sente vorazmente a necessidade de dominar, sem perceber que as próprias baratas que percorrem a biblioteca, numa metáfora clara que antecipa a ruína familiar, anunciam o desvario de sua busca obcecada.

No desfecho do livro descobrimos que o irmão alemão não foi, de fato, assassinado pelo nazismo por conta de sua ascendência judaica, refutando, assim, a 
hipótese trágica que mais atormentava e fascinava Ciccio. Por outro lado, é o seu irmão-rival brasileiro, Mimmo, que morava em sua própria casa, que acaba sendo capturado pelos militares e torna-se um desaparecido político do regime. Habilmente, a narrativa deixa no ar a dúvida se Ciccio, imerso em suas divagações, ignorava a atuação política de seu irmão ou se este fora preso por engano, apenas por querer incluir uma militante argentina em sua lista de conquistas sexuais - como acredita o narrador. Assim, a morte que devastará a família nada tem a ver com o segredo do passado e do irmão alemão, tão remoído por Ciccio, mas por uma violência que se situa em terreno doméstico, próxima aos personagens e que, a despeito dos diversos indícios que o narrador encontra ao longo da história, não recebia da parte dele a idealização fatalista que reservava para fantasiar a morte do irmão alemão como vítima da Shoah.

\section{Considerações Finais}

A breve leitura que propomos desses três romances permite estabelecer algumas hipóteses a respeito da presença da Shoah na recente literatura brasileira. Em primeiro lugar, assim como no cenário examinado por Márcio Seligmann-Silva, os autores que mais se dedicam ao tema são judeus - familiares de imigrantes e/ou sobreviventes da Segunda Guerra Mundial, como nos casos de Bernardo Kucinski e Noemi Jaffe -, embora possamos afirmar que o assunto não se restringe exclusivamente a esse grupo, ganhando destaque também em escritores sem vínculo com o judaísmo, como Chico Buarque.

Observamos também que os três romances pertencem a nomes prestigiados da literatura contemporânea, todos eles publicados em editoras de grande projeção e recebendo acolhida crítica amplamente elogiosa. Assim, nos parece que a Shoah tem deixado de ser um assunto estranho ou voltado para um nicho de leitores específico. Isso se evidencia, ainda, na relação entre as obras analisadas e tendências artísticas valorizadas no debate sobre a produção contemporânea, como o hibridismo de gêneros, o romance testemunhal e a autoficção.

O que os cegos estão sonhando? indica a persistência do testemunho primário como parte fundamental do debate sobre a Shoah, articulando a ele questões de representação, transmissão e preservação da memória traumática, a partir dos testemunhos dos filhos de sobrevivente. K. Relato de uma busca e O irmão alemão 
destacam-se por evocar o horror extremo dos campos de concentração nazistas como contraponto para a reflexão sobre as catástrofes do século XX, com foco na barbárie imposta pela ditadura militar no Brasil. Ambos estabelecem, em seus enredos, fissuras entre a memória da Shoah - ainda alimentada com vigor pelas representações midiáticas e consagrada como símbolo global da máxima crueldade - e o recalque cultural da violência da ditadura brasileira, especialmente em uma de suas faces mais perversas, a do desaparecimento dos corpos de suas vítimas.

Assim, buscam resistir ao definhamento da memória imposto pelas políticas hegemônicas de esquecimento, e reconstituir, pela literatura, uma história alternativa de nosso passado recente. Longe de atenuarem a experiência-limite da Shoah em prol de um redimensionamento da catástrofe brasileira, as obras indicam, com K. e Ciccio, a necessidade de vigília constante: uma memória ativa que não leve à negligência em relação ao presente, tendo em vista as muitas manifestações do autoritarismo e sua dimensão destruidora.

\section{Referências}

BUARQUE, C. O irmão alemão. São Paulo: Cia. das Letras, 2014.

GAGNEBIN, J. M. Lembrar escrever esquecer. São Paulo: Editora 34, 2009.

GAGNEBIN, J. M. Palavras para Hurbinek. In: NESTRÓVSKI, A.; SELIGMANNSILVA, M. Catástrofe e Representação. São Paulo: Escuta, 2000.

KUCINSKI, B. K. Relato de uma busca. São Paulo: Cosac Naify, 2014.

KUCINSKI, B. Os visitantes. São Paulo: Cia. das Letras, 2016.

JAFFE, N. O que os cegos estão sonhando? São Paulo: Editora 34, 2012.

LAUB, M. Diário da queda. São Paulo: Cia. das Letras, 2011.

MOSCOVICH, C. Anotações durante o incêndio. Porto Alegre: L\&PM, 2001. p. 36.

NORONHA, J. M. G. Ensaios sobre a autoficção. Belo Horizonte: Editora UFMG, 2014.

PAULA, M. F. de. O testemunho oblíquo em $O$ que os cegos estão sonhando?, de Noemi Jaffe, e Maus, de Art Spiegelman. Revista Estud. Lit. Bras. Contemp. 2018, Brasília, n. 55, p. 285-308. Disponível em: <http://www.scielo.br/scielo.php?script=sci_arttext\&pid=S231640182018000300285\& Ing=en\&nrm=iso>. Acessado em 25 Nov. 2020. 
SANCHES NETO, M. A segunda pátria. São Paulo: Intrínseca, 2015.

SELIGMANN-SILVA, M. Literatura da Shoah no Brasil. Arquivo Maaravi: Revista de Estudos Judaicos da UFMG. 2007, Belo Horizonte, vol. 1, nº 1.

WALDMAN, B. Uma história concisa do Holocausto na literatura brasileira. Arquivo Maaravi: Revista de Estudos Judaicos da UFMG. 2019, Belo Horizonte, vol. 13, nº 25.

Recebido em 14/10/2020

Aceito em 01/12/2020

Publicado em 20/12/2020 